\title{
A Giant Fetal Urinoma in a Neonate without Detectable Obstructive Uropathy
}

\begin{abstract}
Fetal urinoma is an uncommon finding in prenatal investigations. Most previous reports have, almost in every case, referred to the presence of an obstructive uropathy and thus to very high pressure in the upper urinary tract during fetal life. In this paper we present a prenatally detected fetal giant urinoma occurring in the absence of an apparent obstructive uropathy but associated with an ipsilateral vesico-ureteral reflux.

Case Report: A 5-day-old boy, born after a caesarian section in the 37th week of gestation, but without any perinatal distress, came under our observation because of the evidence of a right upper quadrant abdominal mass. This mass had already been detected prenatally, when during the 30th week of gestation ultrasound investigation showed a right anechogenic mass occupying more than half of the abdominal fetal profile. At postnatal US scan this liquid mass did not seem to have its own wall and moved the nearest organs laterally and upward. The right kidney was not visualised and no ascites was present. We decided to insert a percutaneous drainage tube to decompress the renal parenchyma; normal urine leaked out from it. Radionuclide 99 mTc-DTPA scan excluded an obstructive uropathy, while voiding cystourethrogram excluded posterior urethral valves but showed a vesico-ureteral reflux. We diagnosed a right-sided giant urinoma correlated with a vesico-ureteral reflux but without any urinary obstruction.
\end{abstract}

Discussion: It is very difficult to find a reasonable explanation for the occurrence of a urinary extravasation as a consequence of a vesico-ureteral reflux as seen in this neonate. We know that an intra-renal reflux can be the final result of high-grade vesicoureteral reflux, but we find it very strange that this could induce a parenchymal rupture in the absence of a rapid increase of pressure and thus without a urinary stricture or stenosis. We can only assume that a prenatal transient urethral outflow obstruction was the cause of this renal rupture. A syringocoele might be the most probable transitory cause of prenatal obstruction.

\section{Key words}

Fetal urinoma - vesico-ureteral reflux $\cdot$ neonate $\cdot$ percutaneous nephrostomy $\cdot$ syringocele

\section{Résumé}

L'urinome fotal est une découverte exceptionnelle des investigations prénatales. La quasi totalité des cas décrits dans la littérature concernent des uropathies obstructives où les voies urinaires hautes sont soumises à des pressions élevées. Nous présentons le cas d'un urinome géant fotal qui s'est développé en l'absence d'une uropathie obstructive mais en association avec un reflux vésico-urétéral ipsilatéral.

Un garçon de cinq jours nous a été adressé en raison d'une masse abdominale importante constatée à la naissance. L'enfant était né par césarienne à 37 semaines sans détresse périnatale. La masse avait été détectée lors de l'échographie réalisée à la 30ème semaine de gestation. Il s'agissait d'une masse anéchogén située dans la partie haute de l'abdomen droit occupant plus de la moitié du profil fotal abdominal. A l'échographie postnatale la masse liquidienne refoulait les organes proches et ne semblait pas avoir une paroi propre. Le rein droit n'était pas visualisé et l'absence d'ascite était confirmée. L'insertion percutanée d'un drain de décompression a permis de retirer de l'urine normale. Une scintigraphie au ${ }^{99} \mathrm{~m} T c-D T P A$ a démontré l'absence d'uropathie obstructive. Un cysto-uréthrogramme permictionnel a éliminé la présence de valves uréthrales postérieures et a mis en évidence un reflux vésico-urétéral ipsilatéral. Nous avons retenu 
le diagnostic d'un urinome géant en rapport avec un reflux vésico-urétéral sans obstruction urinaire.

La raison pour laquelle un reflux vésico-urétéral pourrait avoir comme conséquence une extravasation urinaire n'est pas évidente. Si le reflux intrarénal est bien décrit comme conséquence finale d'un reflux vésico-urétéral important, il est difficile d'imaginer comment une rupture du parenchyme rénal pourrait se produire en l'absence d'une augmentation rapide de la pression et de plus en l'absence d'une sténose des voies urinaires. Notre seule hypothèse est une obstruction prénatale transitoire dont la cause la plus probable serait un syringocèle.

\section{Mots-clés}

Urinome fotal · reflux vésicourétéral · nouveau-né · néphrostomie percutanée . syringocèle

\section{Resumen}

El urinoma fetal es un hallazgo poco frecuente en los estudios de imagen prenatales. La mayoría de los casos previamente publicados estaban relacionados con una uropatía obstructiva y por lo tanto con una presión muy alta en el aparato urinario superior durante la vida fetal. Presentamos un caso de urinoma gigante fetal detectado prenatalmente en ausencia de uropatía obstructiva y asociado con reflujo vesicoureteral del mismo lado.

Caso clínico: Niño de 5 días nacido por cesárea en la semana 37 de la gestación sin sufrimiento fetal que nos es confiado por una masa abdominal en el cuadrante superior derecho. Esta había sido detectada prenatalmente en la semana 30 como una masa anecoica derecha que ocupaba más de la mitad del abdomen fetal. Tras el nacimiento la ultrasonografía no demostró pared propia en esta masa que desplazaba los órganos cercanos lateralmente y hacia arriba. No se visualizaba el riñón derecho y no había ascitis. Al insertar un drenaje percutáneo para descomprimir el parénquima renal salió orina. Un estudio isotópico con 99 mTc.DTPA excluyó la uropatía obstructiva mientras que una cistografía miccional permitió excluir válvulas de uretra posterior pero mostró un reflujo vesicoureteral. Diagnosticamos un urinoma gigante derecho en relación con reflujo y sin obstrucción.
Discusión: Es difícil encontrar una explicación razonable para la aparición de una extravasación urinaria debida a reflujo en el recién nacido. Sabemos que el reflujo intrarenal puede ser el resultado final de un reflujo vesicoureteral de alto grado pero nos parece muy raro que esto pueda causar una rotura parenquimatosa en ausencia de un aumento rápido de la presión particularmente en ausencia de estenosis.

Solamente podemos concluir que aumentos transitorios de la presión de salida uretral fueran la causa de la rotura renal. Un siringocele podría haber sido la causa de la obstrucción prenatal

\section{Palabras clave}

Urinoma fetal $\cdot$ reflujo vesicoureteral $\cdot$ recién nacido $\cdot$ nefrostomía percutánea $\cdot$ siringocele

\section{Zusammenfassung}

Die pränatale Diagnose eines großen Urinoms ist ungewöhnlich. Es wird deshalb ein 5 Tage alter Knabe mit einem großen Urinom vorgestellt. Eine obstruktive Uropathie konnte nicht nachgewiesen werden, jedoch ein ipsilateraler, vesiko-ureteraler Reflux. Die Diagnose erfolgte pränatal in der 30. SSW. Der Knabe wurde in der 37. Woche durch Sectio entbunden. Der postnatale Ultraschall verifizierte die pränatale Diagnose. Die rechte Niere konnte nicht dargestellt werden, Aszites war nicht nachweisbar. Es wurde eine perkutane Drainage gelegt und mittels Radionuklid 99 mTc-DTPA eine obstruktive Uropathie ausgeschlossen. Ein später durchgeführtes MCU konnte eine subvesikale Obstruktion ausschließen, zeigte jedoch einen vesiko-ureteralen Reflux. Die Arbeit wirft die Frage auf, ob tatsächlich ein Urinom durch einen vesiko-ureteralen Reflux entstehen kann, der ja dann zu einem intrarenalen Reflux mit Parenchymruptur führen müsste. Möglicherweise lag bei dem Knaben daher eher eine pränatale, vorübergehende Abflussstörung vor, die die Nierenruptur verursacht hat.

\section{Schlüsselwörter}

Fetales Urinom • vesiko-ureteraler Reflux · Neugeborenes · perkutane Nephrostomie $\cdot$ Syringozele

\section{Introduction}

Fetal urinoma is an uncommon finding in prenatal investigations. Most previous reports have, almost in every case, referred to the presence of an obstructive uropathy, mostly of the posterior urethral valves $(2,3,5,7)$. This can cause a rupture of the renal parenchyma due to a very high pressure in the upper urinary tract during fetal life and subsequently to an intra-renal reflux. The relationship between renal rupture and high pressure in the urinary tract has been confirmed by other reported correlations such as uretero-pelvic junction obstruction $(1,6,11)$, primary obstructive megaureter (4), anterior urethral diverticulum $(13,14)$. Furthermore, some cases have been correlated to Crede's manoeuvre in the neurogenic bladder (12), but only two cases to a vesico-ureteral reflux (10).
In 2000, Ito et al. (8) reported a case of a giant urinoma without obstructive uropathy in a 7-day-old boy with renal failure which, however, was not detected prenatally. They correlated the onset of collected extravasated urine in the perirenal space with certain traumatic factors during delivery and the fragility of the renal capsule.

In a similar case with its own particularities, we present a prenatally detected fetal giant urinoma which occurred in the absence of an apparent obstructive uropathy but which is associated with an ipsilateral vesico-ureteral reflux. 


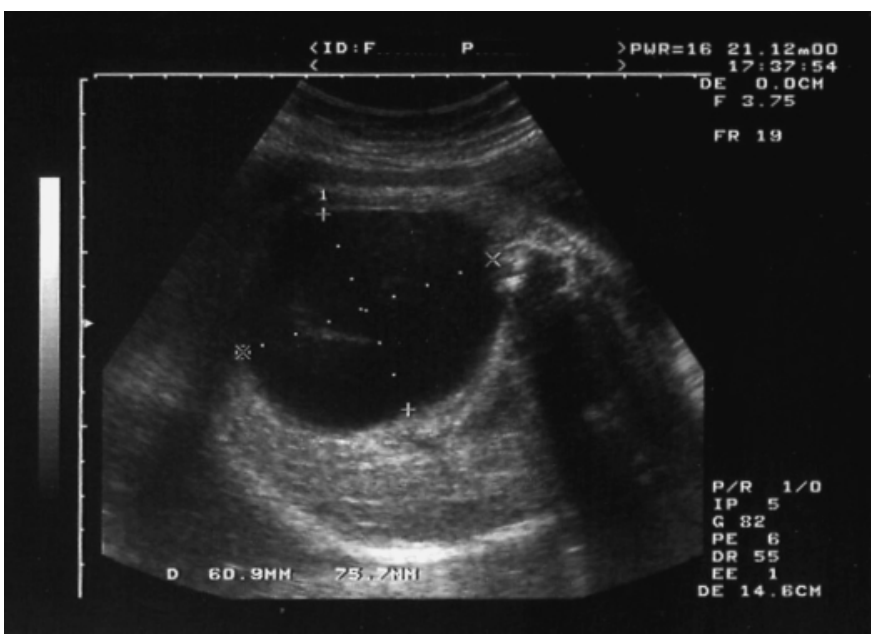

Fig. 1 Prenatal US scan showing a fetal anechogenic right mass.

\section{Case Report}

A 5-day-old boy, born after a caesarian section in the 37th week of gestation but without any perinatal distress, came under our observation for the evidence of a right upper quadrant abdominal mass. There was no consanguinity or family history for uropathies. At birth the baby had adequate weight for his age; Apgar scores were in the normal range; there was no respiratory distress and voiding of urine was normal $(250 \mathrm{ml} / \mathrm{day}, \mathrm{SG} 1007)$. A palpable mass was apparent in the right abdominal quadrant. This mass had already been detected prenatally, when, during the 30th week of gestation, an ultrasound investigation showed a right anechogenic mass, occupying more than half of the abdominal fetal profile (Fig. 1). It is important to note that previous pre-natal US scans (the last one was carried out during the 20th week) never pointed to any solid or liquid mass. The US scan performed postnatally in our institution showed an anechogenic mass located in the right flank, which measured $9.5 \mathrm{~cm} \times 6.5 \mathrm{~cm}$ (Fig. 2). This liquid mass did not seem to have its own wall and moved the nearest organs laterally and upward. The right kidney was not visualised and no ascites was present. Inside the mass, some septa could be seen similar to a multicystic kidney. The left kidney and bladder showed no anomalies. Since we excluded a multicystic kidney but not an obstructive uropathy (i.e. ureteropelvic junction stenosis) we decided to insert a percutaneous drainage tube to decompress the renal parenchyma (Fig. 3) under ultrasonographic guidance. Immediately, $200 \mathrm{ml}$ fluid which had the appearance of normal urine leaked out from the nephrostomy and the subsequent laboratory report confirmed the normal chemical and physical characteristics of urine with a specific gravity of 1005 . This leaking of urine continued at a high rate for 3 weeks and then began to abate until it disappeared. One hour after the insertion of the percutaneous nephrostomy, we noticed at ultrasound the correct position of the tube inside the liquid mass and the appearance of a normal renal profile related to the right kidney, with a light pelvic dilatation $<15 \mathrm{~mm}$ and a small anechogenic liquid layer surrounding the kidney. During the next few days we proceeded to evaluate renal function separately for the two kidneys. We found increasing diuresis through the nephrostomy, similar to post-obstructive

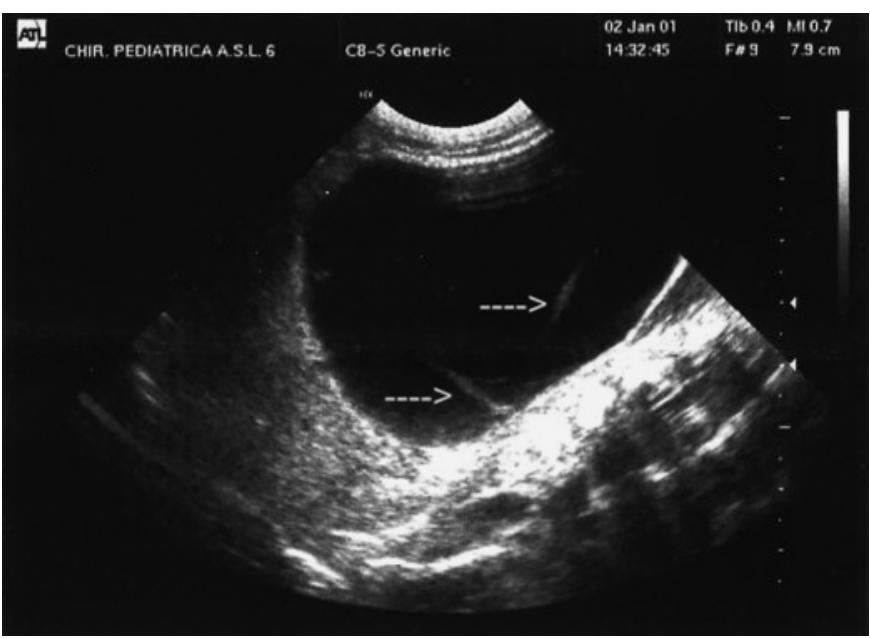

Fig. 2 Postnatal US scan showing the right anechogenic mass. Some septa are indicated by arrows.

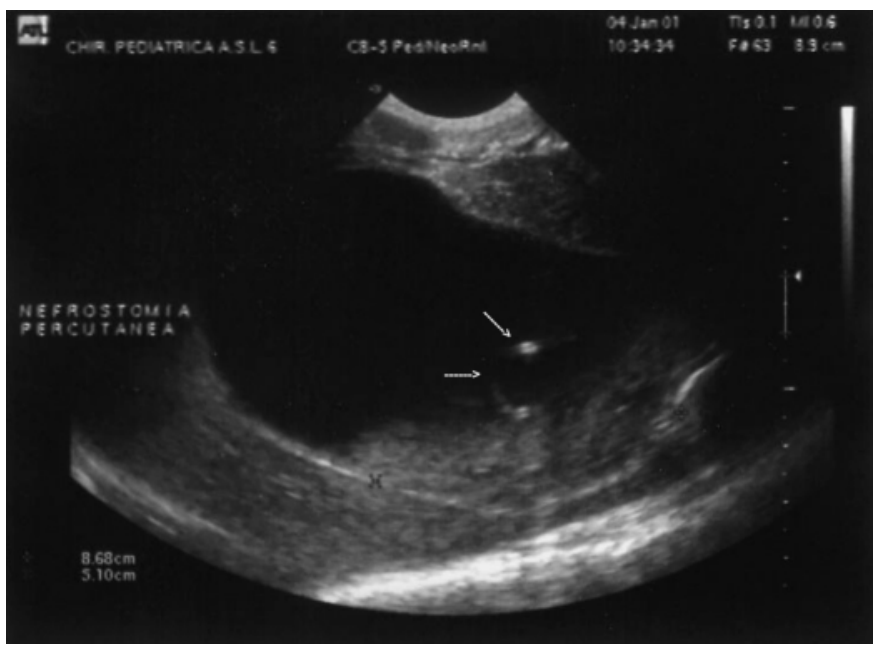

Fig. 3 Arrows show the pigtail correctly inserted in the liquid mass.

polyuria, but with a specific gravity of urine comparable to that the left kidney. Creatinine clearance performed on the 8th and the13th day after insertion of the nephrostomy showed a greater reduction of the filtration ability of the right kidney compared to the left one, with a right value of $24.7-20.7 \mathrm{ml} / \mathrm{min} / 1.73 \mathrm{~m}^{2} \mathrm{vs}$. $45.3-44.3 \mathrm{ml} / \mathrm{min} / 1.73 \mathrm{~m}^{2}$.

In Table $\mathbf{1}$ we show the figures for urinary electrolytes and fractions of electrolyte excretion for both kidneys without any significant differences.

As part of the ongoing investigation we decided to perform a trans-nephrostomy pyelogram, which was intended to demonstrate the presence of a stenosis of the pyelo-ureteral junction (Fig. 4). Initially we thought that the contrast medium had exited via the catheter, producing a perirenal leakage. However, on the contrary, we were then able to show a iatrogenic perirenal urinoma-like mass. 
Table 1 Urinary electrolyte values on the 13th day of life

\begin{tabular}{llll}
\hline \multicolumn{2}{l}{ Left kidney } & \multicolumn{2}{l}{ Right nephrostomy } \\
\hline $\mathrm{Na}^{+}$ & $2.4 \mathrm{mEq} / 24 \mathrm{~h}$ & $\mathrm{Na}^{+}$ & $5.5 \mathrm{mEq} / 24 \mathrm{~h}$ \\
$\mathrm{~K}^{+}$ & $4.14 \mathrm{mEq} / 24 \mathrm{~h}$ & $\mathrm{~K}^{+}$ & $3.3 \mathrm{mEq} / 24 \mathrm{~h}$ \\
$\mathrm{Cl}^{-}$ & $2.6 \mathrm{mEq} / \mathrm{L}$ & $\mathrm{Cl}^{-}$ & $3.5 \mathrm{mEq} / \mathrm{L}$ \\
$\mathrm{FeNa}^{+}$ & $0.032 \%$, & $\mathrm{FeNa}^{+}$ & $0.073 \%$ \\
$\mathrm{FeK}^{+}$ & $0.074 \%$, & $\mathrm{FeK}^{+}$ & $0.059 \%$ \\
$\mathrm{FeCl}^{-}$ & $0.046 \%$ & $\mathrm{FeCl}^{-}$ & $0.062 \%$ \\
\hline
\end{tabular}

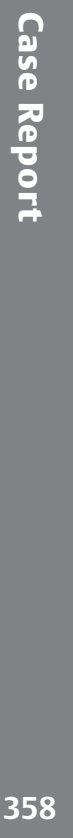

Urinary output/24 h: $200 \mathrm{ml}$ left kidney, $500 \mathrm{ml}$ right kidney

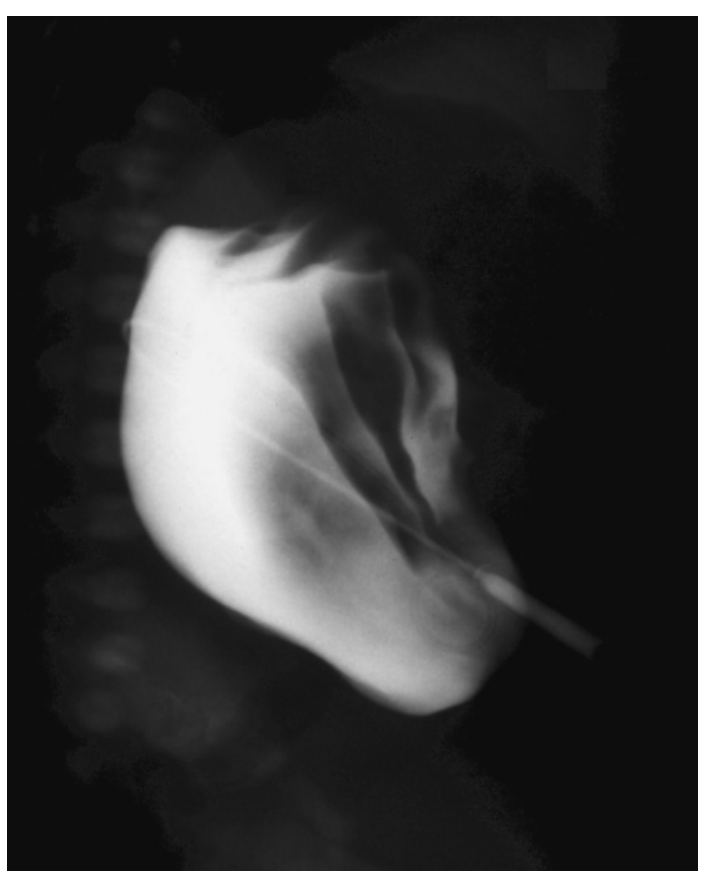

Fig. 4 Percutaneous pyelogram showing extravasation of contrast.
At the age of 22 days, the baby underwent a radionuclide scan with $99 \mathrm{mTc}-\mathrm{DTPA}$, followed by a $1 \mathrm{mg} / \mathrm{kg}$ body weight dose of furosemide: the renogram did not show any obstructive pattern with a GFR of $35 \%$ on the right and $65 \%$ on the left (Fig. 5).

The subsequent voiding cystourethrogram confirmed the presence of a vesico-ureteral reflux but showed no stricture of the urethra, neither of the valves nor at any other places (Fig. 6). A vesical para-ureteral diverticulum was also detected. The leakage from the nephrostomy ended spontaneously on the 45th day and the tube was then removed.

After 6 months of antibiotics prophylaxis, during which the vesico-ureteral reflux remained, we proceeded to a Cohen crosstrigonal ureteral neocystostomy. The cystourethrogram showed a normal radiographic pattern at 1-year follow-up.

\section{Discussion}

We report a rare case of a neonate right liquid mass detected prenatally during the 30th week of gestation, which after postnatal investigation turned out to be a right fetal urinoma. The peculiarity of this urinoma consisted in the absence of any stricture in the uretero-pelvic junction or in other tracts (lower ureter, bladder, posterior and anterior urethra). Diagnosis was not to easy, because at the beginning we supposed and investigated for the presence of a stricture but found only a vesico-ureteral reflux. We accurately detected the posterior and anterior urethra, but when we searched for any masses obstructing the urethral valves or any diverticula, we found none. Because the fluid which leaked from the nephrostomy tube, inserted in the anechogenic mass at an early stage, was very similar to normal urine, there was a reasonable suspicion of an obstructive hydronephrosis or other cystic renal diseases such as multicystic dysplasia, polycystic kidney and, finally, even a Wilms' tumour. After we had excluded everyone of these possible causes, we concluded with a diagnosis of a right giant urinoma which was correlated to a vesico-ureteral reflux, but without any urinary obstruction.

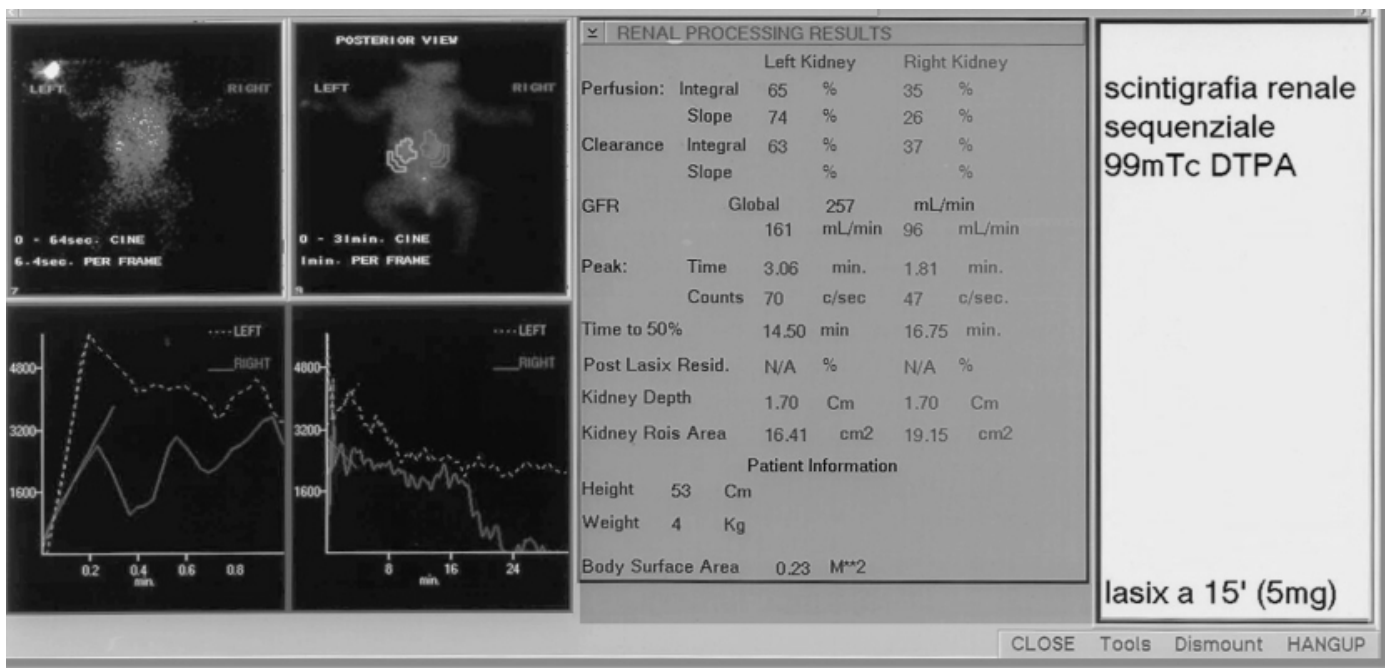

Fig. 5 Radionuclide DTPA scan. No evidence of pyeloureteral junction obstruction at diuretic renogram. 


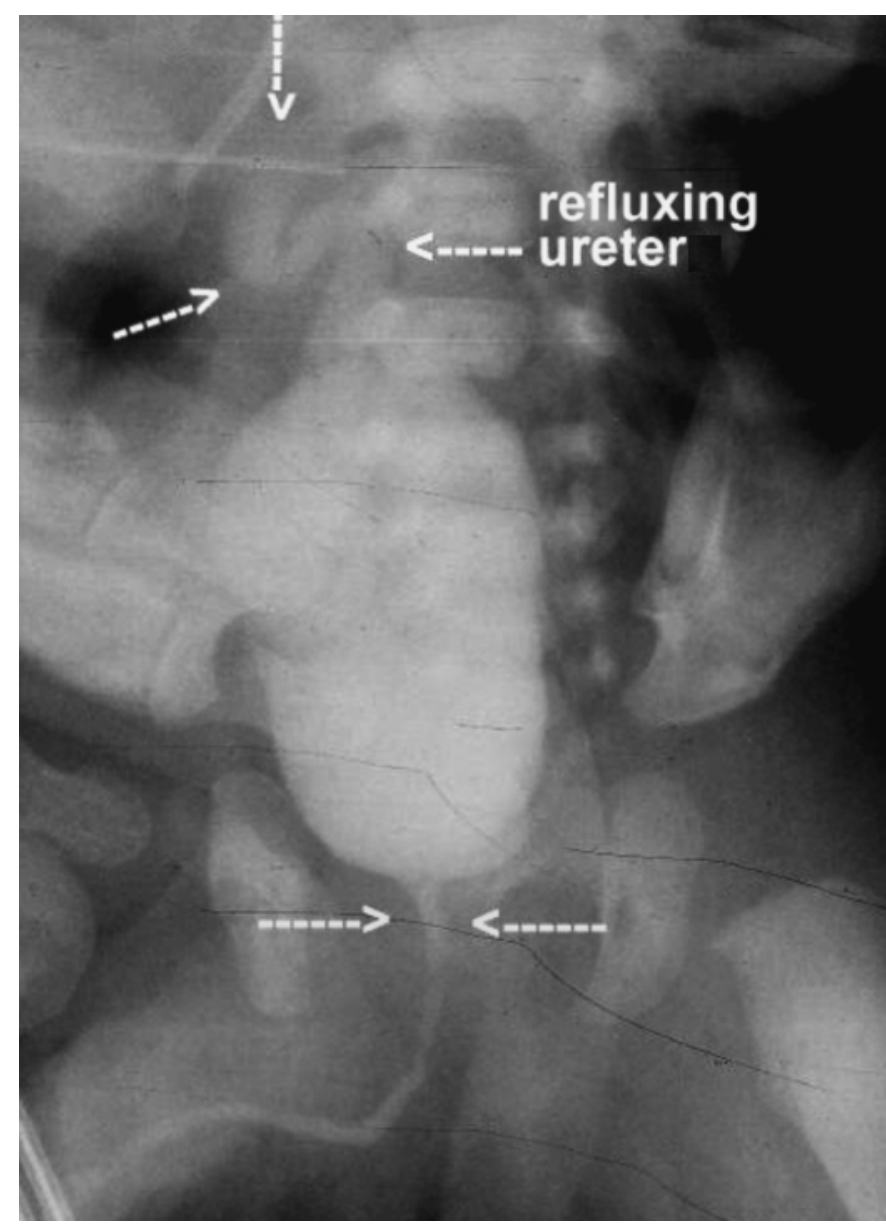

Fig. 6 Voiding cystourethrogram showing the normal appearance of the urethra and a right refluxing ureter.

The cause of urinoma is still uncertain. Urinomas secondary to an obstructive uropathy are easy to correlate, since the renal rupture represents a protective mechanism to reduce the high pressure in the urinary tract and to preserve the integrity of the kidneys. This can occur when posterior urethral valves are present in fetal life (7). Some reports describe a condition of urethral valves and urinoma $(2,3,5)$. Furthermore, the correlation with a sudden increase of intrarenal pressure has been clearly demonstrated by papers in which the occurrence of urinoma was strictly associated to a uretero-pelvic junction stenosis $(1,6,11)$. Urinoma and high urinary pressure have also been correlated in a paper where the renal rupture occurred subsequent to a Credé manoeuvre (12).

Renal injures are rare during delivery; in the report by Ito and coworkers, the authors supposed that a parenchymal rupture during delivery might have caused the extravasation of urine and the urinoma (8). We have found only one paper in which urinoma was associated with a vesico-ureteral reflux (10).

It is very difficult to find a reasonable explanation for the occurrence of a urinary extravasation as consequence of a vesico-ureteral reflux as seen in this neonate. We know that an intra-renal reflux can be the final result of a high grade vesico-ureteral reflux, but we find it very strange that this could induce a parenchymal rupture in the absence of a rapid increase of pressure and thus without a urinary stricture or stenosis. We can only suppose that a prenatal transient urethral outflow obstruction was the cause of this renal rupture. A syringocoele might be the most probable transitory cause of prenatal obstruction.

Another aetiology which could mimic a urinary extravasation is the rupture of a cyst in a very small dysplastic upper pole in the duplex system. In our case, imaging never showed any renal duplication nor was a double ureteral vesical meatus was found at surgery.

Percutaneous drainage was an effective and safe treatment for our patient and helped to make the diagnosis. As reported by Lang et al. (9), over $90 \%$ of patients with urinoma due to obstructive uropathy were successfully treated by percutaneous drainage with relief of the obstruction. In trauma-induced urinomas, drainage is a good first step before surgical correction.

\section{References}

${ }^{1}$ Adzick NS, Harrison MR, Flake AW, deLorimier AA. Urinary extravasation in the fetus with obstructive uropathy. J Pediatr Surg 1985; 20 . $608-615$

${ }^{2}$ Ahmed S, Borghol M, Hugosson C. Urinoma and urinary ascites secondary to calyceal perforation in neonatal posterior urethral valves. Br J Urol 1997; 79: 991 - 992

${ }^{3}$ Balcom AH, Pircon R, Worthington D, Carr M. Spontaneous resolution of an in utero perirenal urinoma associated with posterior urethral valves. Urology 1999; 54: 366 - 367

${ }^{4}$ Bidani N, Herman TE, Radkowski MA, Kieran AM. Uriniferous perirenal pseudocyst in a neonate with primary obstructive megaureter. Clin Nucl Med 1982; 7: 540-542

${ }^{5}$ Claahsen van der Grinten HL, Monnens LAH, de Gier RPE, Feitz WFI Perinatal rupture of the uropoietic system. Clinical Nephrology 2002; 57: $432-438$

${ }^{6}$ Connor JP, Hensle TW, Berdon W, Burbige KA. Contained neonatal urinoma: management and functional results. J Urol 1988; 140: $1319-$ 1322

${ }^{7}$ Donnelly LF, Gylys-Morin VM, Wacksman J, Gelfand MJ. Unilateral vesicoureteral reflux: association with protected renal function in patients with posterior urethral valves. AJR Am J Roentgenol 1997; 168: $823-826$

${ }^{8}$ Ito S, Ikeda M, Asanuma H, Shishido S, Nakai H, Honda M. A giant urinoma in a neonate without obstructive uropathy. Pediatr Nephrol 2000; $14: 831-832$

${ }^{9}$ Lang EK, Gloriose L III. Management of urinomas by percutaneous drainage procedures. Radiol Clin North Am 1986; 24: 551 - 559

10 Passas V, Vasilakos P, Brountzos E, Grilias D. An unusual encapsulated collection of urine (urinoma) in an infant with vesicoureteral reflux. Pediatr Radiol 1987; 17: 422-424

${ }^{11}$ Patti G, Galluzzo M, Rastelli D, Bellussi A, Miele V, Calisti A. Fetal urinoma caused by pyelo-ureteral obstruction: spontaneous remission. Pediatr Med Chir 1999; 21: 97 - 99

12 Reinberg Y, Fleming T, Gonzalez R. Renal rupture after the Credé maneuver. J Pediatr 1994; 124: 279-281

${ }^{13}$ Sirota L, Katz R, Samuel N, Bar-Ziv J, Dulitzky F. Congenital anterior urethral diverticulum associated with bilateral urinomas and dysplastic kidneys. Helv Paediatr Acta 1986; 41: 353 - 357

14 Soulez G, Montagne JP, Faure C, Gruner M. Urinoma in newborn infants complicating congenital uropathy. 4 cases. J Radiol 1989; 70: $471-476$ 